\title{
Optimization of ethanol determination in wine by enzyme amperometric biosensor
}

\author{
T.B. Goriushkina ${ }^{1,2}$, A.P. Orlova ${ }^{1,2}$, G.M.Veryk ${ }^{3}$, A.P. Soldatkin ${ }^{1}$, S.V. Dzyadevych ${ }^{1}$
}

${ }^{1}$ Institute of molecular biology and genetics NAS of Ukraine

150, Zabolotnogo Str, Kyiv Ukraine, 03680

${ }^{2}$ National Taras Shevchenko University of Kyiv

64, Volodymyrska Str, Kyiv, Ukraine 01033

${ }^{3}$ Institute for Vine and Wine "Magarach"

31 Kirov St., Yalta, Crimea, Ukraine, 98600

tatiana_goryushkina@yahoo.com

\begin{abstract}
The paper presents a comparative analysis of two methods of alcohol oxidase (AO) immobilization for the development of amperometric biosensor for ethanol determination in wine. A method of AO immobilization in glutaraldehyde vapour appeared to be an optimal one for this purpose. The selectivity, operational and storage stability, and $\mathrm{pH}$-optimum for operation of the created biosensor were determined. The procedure of ethanol determination in wine by the amperometric biosensor, based on platinum printed electrode SensLab and AO, was optimized. The analysis of ethanol concentration in several wine and must samples was carried out using the developed high-stable biosensor. A good correlation between data obtained by the biosensor and densitometry methods was obtained.
\end{abstract}

Keywords: amperometric biosensor, alcohol oxidase, ethanol, wine, must.

The procedure of ethanol determination in wine by enzyme amperometric biosensor

Summary

Aim. Development of the procedure of ethanol determination in wine by an enzyme amperometric biosensor. Methods. The amperometric biosensor method of ethanol analysis has been used in this work. Results. The paper presents comparative analysis of two methods of alcohol oxidase (AO) immobilization for development of amperometric biosensor for ethanol determination in wine. The method of AO immobilization in glutaraldehyde vapour was chosen as optimal for this purpose. The selectivity, operational and storage stability, and pH-optimum for operation of the created biosensor were determined. The procedure of ethanol determination in wine by amperometric biosensor on the basis of platinum printed elec-

(c) Institute of Molecular Biology and Genetics NAS of Ukraine, 2009 trode SensLab and AO was optimized. The analysis of ethanol concentration in wine and must samples was carried out using the developed high-stable biosensor. A good correlation between the data obtained by the biosensor and densitometry methods was shown. Conclusion. The proposed method of ethanol analysis could be used in wine production.

Introduction. Ethanol is a main product of yeast fermentation of grape must sugars. An actual yield of ethanol is $0.58-0.60 \mathrm{ml}$ per $1 \mathrm{~g}$ of sugar and depends on the yeast state and race. The dry table wines are characterized by low alcohol content, $100 \%$ of which is of endogenous origin. The dessert wines contain much more alcohol, $80-90 \%$ of which is added exogenously [1]. 
Ethanol content in wines should be strictly controlled at all stages of winemaking because of its physiological effect on human organism [2]. It is ethanol, which calls forth toxic properties of alcoholic drinks, its high concentration can result in alcoholic intoxication $[1,3]$. Thus, safe consumption of wines and other alcoholic drinks is determined by the amount of ethanol introduced into an organism. Besides, an increase in ethanol concentration in the must has a negative effect on yeast growth and development during wine fermentation [1]. Therefore, permanent ethanol measurement, along with an analysis of other key components, is necessary from economical viewpoint to optimize fermentation process and prevent its disorder $[1,4]$.

An analysis of three-phase system which is the must at fermentation is rather a challenge. It is a complex mixture of sugars, organic acids, proteins, amino acids, pigments, tannins, aromatic substances, vitamins, enzymes, mineral salts, besides, there can be grape solid particles, microorganisms, and gases $[1,5]$. Wine is also a complex of over 500 different organic and inorganic compounds: alcohols, aldehydes, ketones, ethers, carbohydrates, acids, as well as phenolic, nitrogenous, mineral, and biologically active substances [1]. This is why, tested components variety and medium heterogeneity are key factors to be taken into account at the wine and must analysis. Correspondingly, a method suggested for measurement of a certain wine component should be based on the principles providing maximum selectivity to a target analyte. Since the compound content essentially changes depending on the wine variety, it is important to ensure measurement of the target analyte in wide concentration range and to take into account the presence of interfering substances, amount and composition of which are also different in diverse types of wine materials and wines [6].

Traditionally, ethanol in wine is determined by gas chromatography as well as by alcohol distillation with subsequent distillate densitometry and refractometry $[1,2]$. These approaches can give reliable results, however, the distillation method is low specific towards ethanol because of the presence of other light compounds, which are distilled together with the alcohol [2]. In addition, the classical methods require too much of time consumption, highly experienced personnel, sample special pretreatment, expensive and/or large equipment
[1]. Besides, the traditional devices are immobile, cannot be automated and adopted to the needs and financial conditions of minor wineries, which require cheap and reliable tools $[7,8]$.

Taking into consideration the above stated, the enzyme amperometric biosensors seem to be attractive alternative to the traditional analytical methods and, thus, their application is one of the most prospective approaches to solving the problems of fast, cheap and reliable determination of ethanol in complex mixtures must and wines [4]. Therefore, during last years the biosensors are more and more widely used for the analysis of production quality in food industry including winemaking [9].

Alcohol oxidase (AO), an enzyme produced by methylotrophic yeast Hansenula, Pichia, Candida, seems to be the most appropriate enzyme for development of amperometric biosensors. AO is an oligomeric block consisting of eight identical subunits organized in quasi-cubical system, each of which contains strongly bound cofactor PAD [10]. Owing to this, there is no need to introduce the cofactor exogenously that simplifies an analytical procedure [4]. The developed amperometric biosensors based on immobilized $\mathrm{AO}$, have wide dynamic range from 0.1 to $30 \mathrm{mM}$ of the substrate concentration [10], which well corresponds to the variation of ethanol concentration in wines and wine materials.

However, numerous AO based amperometric biosensors developed up to date are to some extent disadvantageous compared to the traditional methods of ethanol analysis in wine. The most important challenge is their low stability and insufficient selectivity [4].

It is known, that enzymes removed from the natural medium exhibit a tendency to fast loss of the activity that limits the time of biosensor working capacity [11]. The data $[12,13]$ showed that AO is an enzyme with low stability: it demonstrates only $50 \%$ of original activity in $16-18$ days after immobilization. Other investigations found that the signal of the $\mathrm{AO}$ based biosensor in one-month storage was $60 \%$ [14] and $30 \%$ [15, 16] of the original level.

Noteworthy, that in $[13,14]$ the AO immobilization on the surface of platinum electrodes was carried out electrochemically in osmium-containing [13] and acryl [14] polymers, in [12] AO was immobilized in 
polycarbamoylsulphite hydrogel, in $[15,16]$ - on carbon electrodes in glutaraldehyde. For the moment, it has been established that enzyme stability depends, along with other factors, on a method of its immobilization on the electrode surface, an effect of sensitive membrane components on the enzyme function and selection of the electrode material [4]. As shown in [17], the AO-based biosensor with gold electrodes and the enzyme, immobilized by cross-linking with BSA in glutaraldehyde, demonstrated almost 100\% activity after 90 measurements.

The reason of low biosensor selectivity to the substrate can be sensitivity of the enzyme membrane and/or the surface of amperometric electrode towards the interfering substances in wine, which are oxidized on the electrode. Inadequate results of the biosensor analysis of wine and must can be also obtained if some wine components act as activators, inhibitors and even alternative substrates of the immobilized enzyme [19].

Study on selectivity of the biosensors based on immobilized AO shows that regularly they are sensitive to lactate $[16,18]$, acetate [18], and especially to methanol $[17,18]$ and ascorbic acid $[16,18]$. A non-specific signal to ascorbic acid appears because of its electrochemical oxidation on the electrode at high working potential. This signal can be decreased by usage of lower potential, but it negatively influences the biosensor sensitivity [20]. Oxidations of one chain aliphatic alcohol methanol, structurally similar to ethanol, as well as non-specific oxidation of lactate and acetate, are basically catalyzed by AO itself [18]. To avoid these effects, the wine samples analyzed should be diluted as much as possible. Thus, an optimization problem arises concerning the dilution ratio which has to correspond to the definite sensor sensitivity towards a measured substrate and can be used for analyzing strong as well as dry wines with lower ethanol content.

Investigation and optimization of stability and selectivity of the enzyme biosensor as well as elaboration of the wine analysis procedure were the goal of this research, as an important stage, preceding an application of the device in winemaking.

Materials and methods. Materials. Alcohol oxidase was from Hansenula $s p$ with activity of 1.6 U/mg produced by "Sigma-Aldrich" (Great Britain).
Monomer 3,4- ethylenedioxythiophene (EDT), production of Baytron M (Germany), and poly(ethylene glycol) 1450, production of «Sigma» (Switzerland) were used as a matrix for enzyme electrochemical polymerization. Bovine serum albumin (BSA), production of «Sigma-Aldrich Chimie S.a.r.l.» (France), and glutaraldehyde, production «Fluka» (Switzerland), were used for enzyme immobilization.

Reagents $\mathrm{Na}_{2} \mathrm{HPO}_{4} \cdot 7 \mathrm{H}_{2} \mathrm{O}, \mathrm{KH}_{2} \mathrm{PO}_{4}, \mathrm{NaCl}, \mathrm{NaOH}$, $\mathrm{HCl}$, hydrogen peroxide («Phargomed», Ukraine), sodium lactate («Sigma», USA), glucose and L-ascorbic acid («Sigma-Aldrich Chimie S.a.r.l.», France), ethanol («Fluka», Germany), glycerol (Ukraine) were also used. All the reagents, both domestic and imported, were of analytical reagent grade and used as received without additional purification.

Measurement. All electrochemical experiments were carried out using traditional three-electrode system, in which the printed electrode SensLab («SensLab $\mathrm{GmbH»,} \mathrm{Leipzig,} \mathrm{Germany)} \mathrm{is} \mathrm{a} \mathrm{combination} \mathrm{of} \mathrm{all}$ three electrodes, i.e. working platinum, auxiliary and referent ones. Our preliminary research [20] showed that bare SensLab electrodes with no enzyme membranes do not respond to wine, must and their basic components, and therefore can be useful in the biosensors for wine analysis.

Reproducibility and workability of printed platinum electrodes SensLab were tested in the potential range of $0-600 \mathrm{mV}$ (potential scan rate of $20 \mathrm{mV} / \mathrm{s}$ ). Cyclic voltamperometry was performed with the PalmSens potentiostate (Palm Instruments BV, Netherland).

Amperometric measurement was carried out with the PalmSens potentiostate at direct voltage of +200 $\mathrm{mV}$ in 5-ml electrochemical cell.

AO immobilization by electrochemical polymerization in polymer poly(3,4- ethylenedioxythiophene). Electrochemical polymerization of small monomers is one of the most novel approaches to membrane formation on the electrode surface, which has been already a success in biosensorics. This method allows to choose and keep constant film shape and thickness, and to control accurately precipitation [20]. Electropolymerized films, due to their semipermeability towards hydrogen peroxide and impermeability for other compounds, act as a selective barrier, which suppresses interfering ef- 


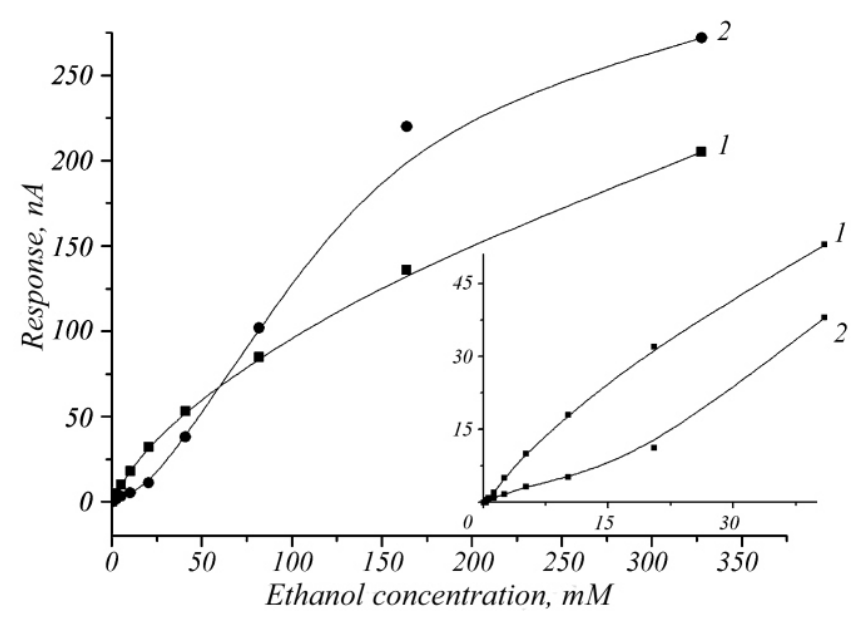

Fig. 1. Calibration curves of laboratory prototypes of amperometric biosensors based on alcohol oxidase, immobilized in BSA-containing membrane in glutaraldehyde vapour (1) and electrochemically polymerized in polymer PEDT (2). Measurement in $20 \mathrm{mM}$ phosphate buffer, $\mathrm{pH} 7.2$, potential of $+200 \mathrm{mV}$ vs reference electrode.

fect of electroactive substances, such as ascorbic acid, often present in must, wine and other real liquids [10, 21].

The enzyme immobilization by electrochemical polymerization in the polymer poly $(3,4-$ ethylenedioxythiophene) (PEDT) is thoroughly described in [20]. The component mixture, consisting of $10 \mathrm{mM} \mathrm{3,4-} \mathrm{ethylenedioxythiophene} \mathrm{(EDT),}$ $1 \mathrm{mM}$ polyethylene glycol and 30\% AO solution, was prepared in $20 \mathrm{mM}$ phosphate buffer, $\mathrm{pH}$ 6.2. EDT was electropolymerized by voltage from $+0.2 \mathrm{~V}$ to $+1.5 \mathrm{~V}$ applied during 15 cycles at a rate of $0.1 \mathrm{~V} / \mathrm{s}$. Electrochemical synthesis of PEDT was controlled using cyclic voltamperometry.

AO immobilization in glutaraldehyde vapour. Glutaraldehyde (GA) is a polyfunctional agent, which forms covalent binding between biocatalytic particles or proteins. That is why the enzyme immobilization with GA is often utilized at the biosensor development. In three-dimensional matrix, obtained by this method, an enzyme is strongly bound to the electrode material that ensures both retention of a biomolecule within the membrane and efficient electric contact between a biomolecule and electrode surface [22].
To obtain bioselective membranes, the mixture of $30 \%$ AO solution with 5\% BSA (1:1) prepared in 10 $\mathrm{mM}$ phosphate buffer, $\mathrm{pH} 7.2$, was deposited on the electrode working surface. For the membrane polymerization, the transducers were placed into saturated GA vapour for $10 \mathrm{~min}$, and then dried in the open air.

Ethanol determination in model solutions. Measurement was carried out at room temperature in an open vessel at intensive stirring. $20 \mathrm{mM}$ solution $\mathrm{KH}_{2} \mathrm{PO}_{4}-\mathrm{Na}_{2} \mathrm{HPO}_{4}$, pH 7.2, was used as a working buffer, $\mathrm{NaCl}(10-200 \mathrm{mM})$ - as a base electrolyte.

Substrates concentration was changed by addition of defined aliquots of concentrated solutions. After each signal, the sensor was washed in a buffer solution until the base signal was stabilized.

Ethanol determination in wine and must. Ethanol was analyzed in 23 samples of wines of different kinds made under conditions of microproduction in the "Magarach" Institute of grape and wine, as well as in 2 samples of white and red wine materials. Measurements were carried out at room temperature in an open vessel filled with intensively stirred $20 \mathrm{mM}$ phosphate buffer solution, $\mathrm{pH}$ 7.2.

Ethanol concentration was determined by the method of standard additions. The sample was 2000-fold diluted. After obtaining each response, the sensor was washed by the buffer solution until the base signal stabilization.

Control measurement was made by the method of alcohol distillation with consequent densitometry.

Investigation of operational and storage stability of biosensors. To determine operational stability and reproducibility of biosensor responses, the substrate aliquots $(20 \mathrm{mM})$ and the samples of wine "Port red" $(20 \mu 1)$ were periodically inserted into an electrochemical cell, and the changes of biosensor signal were registered during 8-hour continuous work.

Results and discussion. Operation of AO-based amperometric biosensors is grounded on the enzymatic reaction:

$$
\begin{gathered}
\mathrm{AO} \\
\text { Ethanol } \rightarrow \text { Acetaldehyde }+\mathrm{H}_{2} \mathrm{O}_{2} .
\end{gathered}
$$

The ethanol enzymatic conversion is followed by production of electrochemically active substance, hydrogen peroxide, oxidation of which results in genera- 

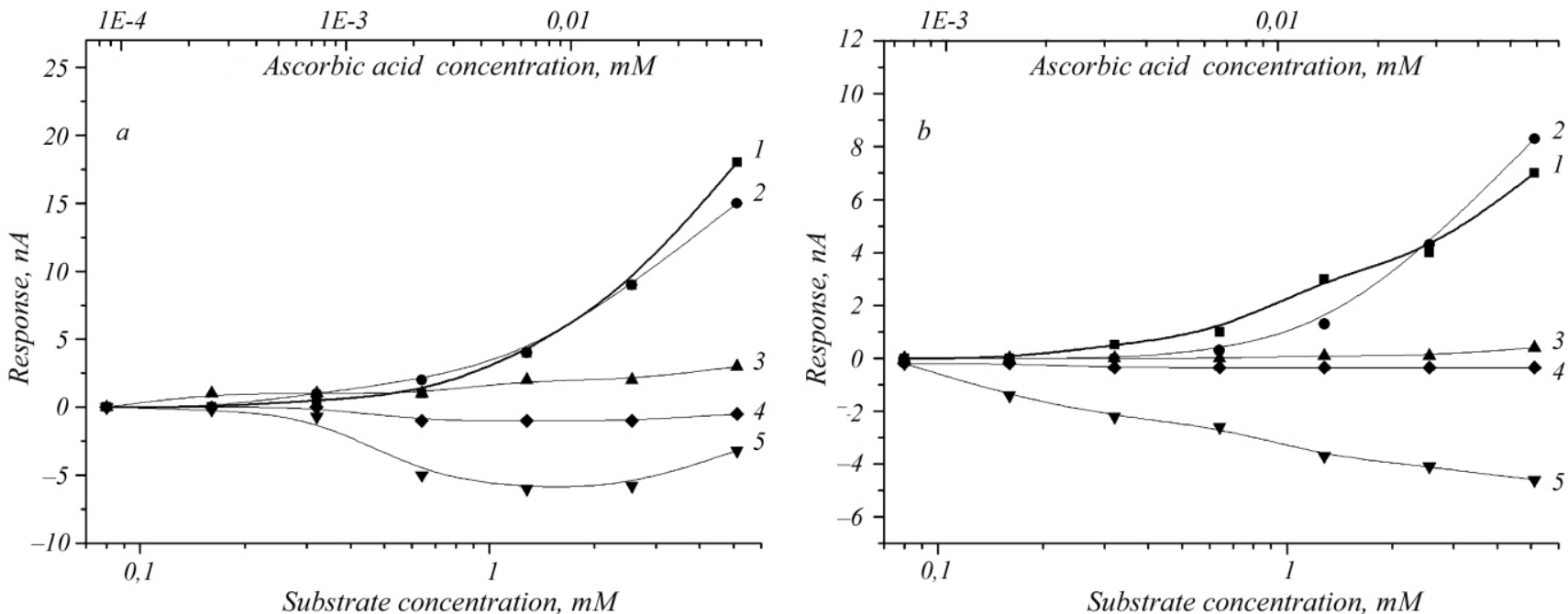

Fig. 2. Responses of laboratory prototypes of amperometric biosensor based on AO, immobilized in GA vapour ( $a$ ) and in polymer PEDT (b), to ethanol (1), glycerol (2), glucose (3), lactate (4), ascorbic acid (5). Measurement in $20 \mathrm{mM}$ phosphate buffer, pH 7.2, potential of $+200 \mathrm{mV}$ vs reference electrode.
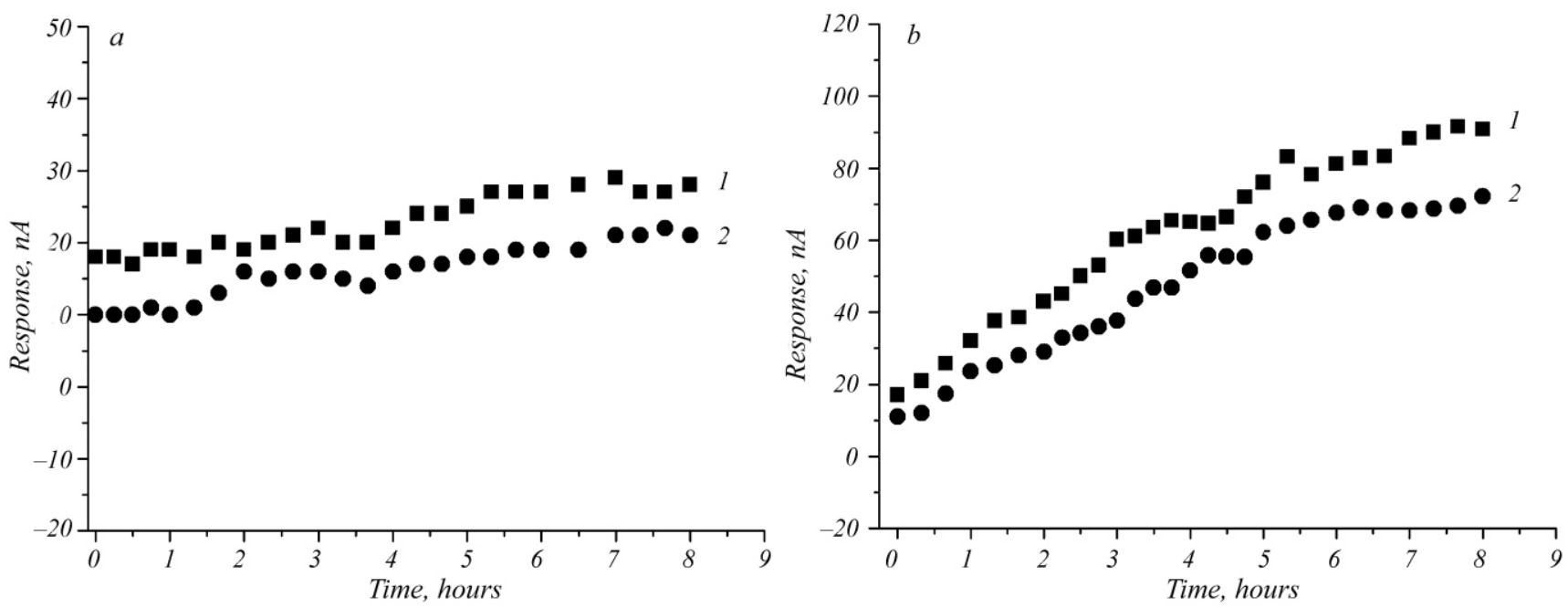

Fig. 3. Operational stability of laboratory prototypes of amperometric biosensors based on AO, immobilized in GA vapour (a) and in polymer PEDT $(b)$. Measurement in $20 \mathrm{mM}$ phosphate buffer, $\mathrm{pH} 7.2$, potential of $+200 \mathrm{mV}$ vs reference electrode. Curve 1 - sensor response to insertion of $20 \mathrm{mM}$ ethanol, curve 2 - that for $20 \mu 1$ sample of "Port red".

tion of electrons registered by an amperometric transducer:

$$
\mathrm{H}_{2} \mathrm{O}_{2} \rightarrow \mathrm{O}_{2}+2 \mathrm{H}^{+}+2 e^{-}
$$

The first stage of research was aimed at selection of the most effective method of AO immobilization on the electrode SensLab surface. Two procedures, different by the technology, were investigated, i.e., electrochem- ical polymerization in polymer PEDT and immobilization in GA vapour in the BSA-containing membrane. The calibration curves of AO-based biosensors using these immobilization methods are presented in Fig. 1. As seen, at start the values of ethanol determination limit and useful signal were lower in the PEDT case. The dynamic ranges are very close for both approaches: $0.32-41 \mathrm{mM}$ for GA method and $0.64-41 \mathrm{mM}-$ for PEDT. 


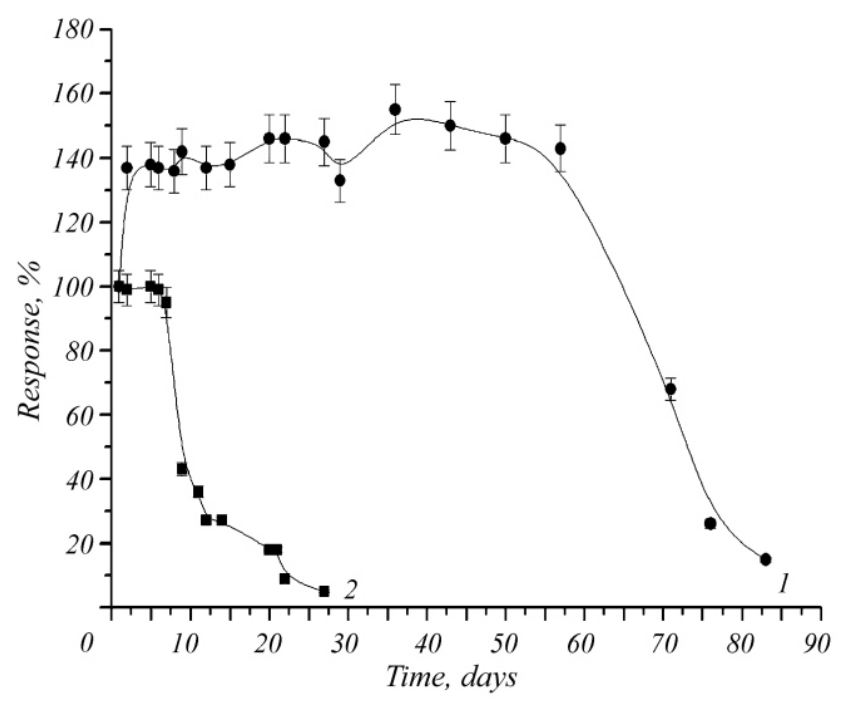

Fig. 4. Dependence of responses of laboratory prototypes of amperometric biosensors based on $\mathrm{AO}$, immobilized in $\mathrm{GA}$ vapour (1) and in polymer PEDT (2) on duration of dry storage at $+4^{\circ} \mathrm{C}$. Measurement in $20 \mathrm{mM}$ phosphate buffer, $\mathrm{pH} 7.2$, potential of +200 $\mathrm{mV}$ vs inner reference electrode, ethanol concentration - $20 \mathrm{mM}$.

To study the selectivity of the developed biosensors, the responses to the components, the presence of which in wine can influence the work of ethanol transducers, i.e., glycerol, glucose, lactate and ascorbic acid, were measured. As seen in Fig. 2a and 2b, the immobilization method has no significant effect on the biosensor selectivity. The AO-based transducers give practically no response to lactate, small negative response to ascorbic acid and positive response to glycerol, the value of which is comparable with that towards ethanol. Noteworthy, that absolute insensitivity to glycerol is not obligatory since ethanol concentration in wine is by dozens of times higher than glycerol content, and this insufficient selectivity can be negligible at sample dilution.

An analysis of operational stability and response reproducibility showed that the biosensors based on PEDT-immobilized AO demonstrated $160 \%$ of initial activity in 8-hour continuous work while those with GA-immobilized AO - about 400\% (Fig. 3a, 3b). This can be a result of gradual increasing of interaction between the immobilized enzyme and the electrode surface; besides, during the first day after immobilization the enzyme molecules acquire an optimal functional conformation in the membrane.
The results on storage stability (Fig. 4) prove that AO electrochemically immobilized in PEDT retains the signal initial level for only one week after immobilization, and then its activity gradually drops. AO immobilized in GA is more stable: in 60-day storage the enzyme demonstrates $133 \%$ initial signal.

Thus, as a result of the comparative analysis of two methods, AO immobilization in GA vapour in BSA-containing membrane was chosen as more effective for ethanol measurement in wine. The biosensor developed with use of this immobilization method is characterized by wide dynamic range of operation, sufficient selectivity and high stability, which allows its application in the wine and must analysis.

The optimum $\mathrm{pH}$ for the biosensor based on $\mathrm{AO}$ immobilized in GA vapour was determined to be 7.2 (Fig. 5a). This value differs from $\mathrm{pH}$ optimum for free $\mathrm{AO}$, $7.5-8.0[23,24]$, which can be explained by the fact that at biosensor functioning the electrochemical reaction takes place along with enzymatic, and this causes certain shift of optimal $\mathrm{pH}$ value [23].

Besides, the response value of this biosensor was shown to be independent on buffer capacity and ion strength of working solution (Fig. 5b), which is typical for amperometric biosensors [4].

At the first stage of work with wine materials, an optimal level of dilution of wine samples was determined regarding their analysis by the developed amperometric biosensor based on AO immobilized in GA. $0.5,1,2.5,5,10$ and $20 \mu 1$ samples of three types of wine with different ethanol contents (10,000-, 5,000-, 1,000-, 500- and 250-fold dilution, correspondingly) were inserted into an electrochemical cell. The wines analyzed were table wine "Mont Blanc", dessert wine "Kara-Dag", and strong wine "Madeira", the ethanol content in which determined by distillate densitometry was $10.5 \%, 16 \%$, and $19 \%$, correspondingly. The responses obtained are presented in Fig. 6. As seen, within the dilution range of $250-2000$ times practically linear dependence between the sample dilution and the biosensor response is observed for all three types of wine while 5,000- and 10,000-fold dilutions are unsuitable for the analysis of dry and dessert wines with low ethanol content. To reduce an effect of interfering substances in wine on the biosensor response, in further experiments the value of samples dilution was 

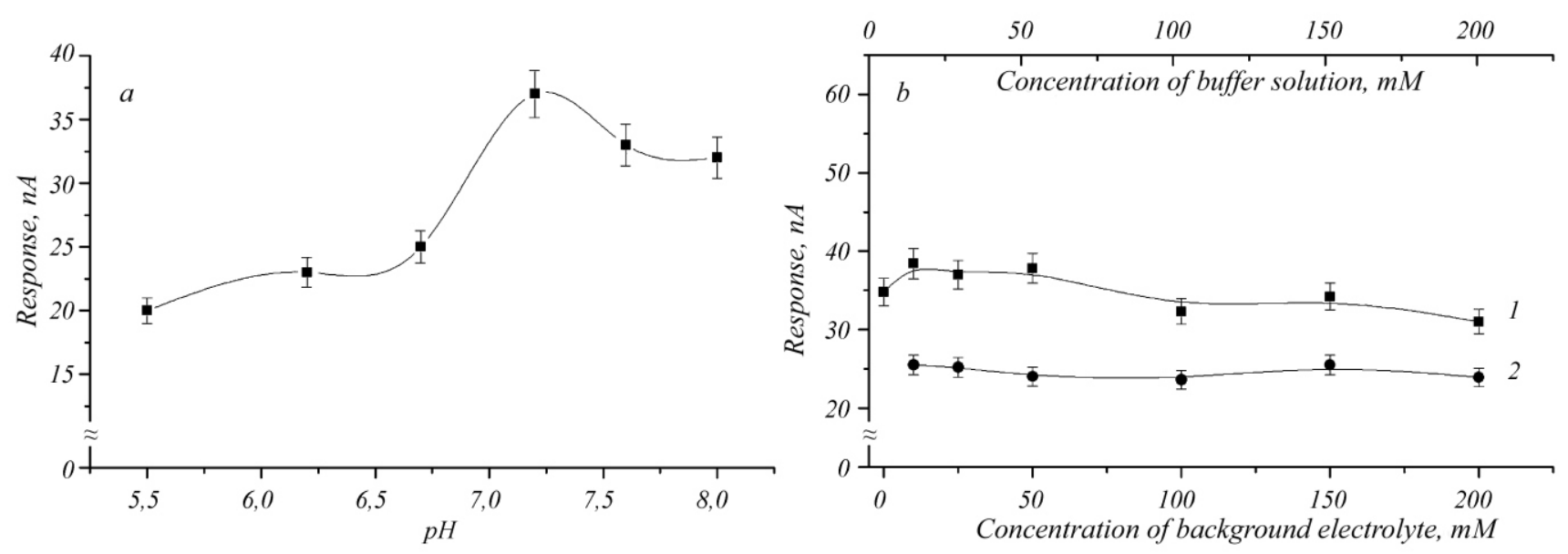

Fig. 5. Dependence of response of amperometric biosensor based on AO, immobilized in GA vapour, on pH of working solution (a), concentration of background electrolyte in buffer $(b$, curve 1$)$, and concentration of buffer solution $(b$, curve 2$)$. Measurement in phosphate buffer, potential of $+200 \mathrm{mV}$ vs inner reference electrode.

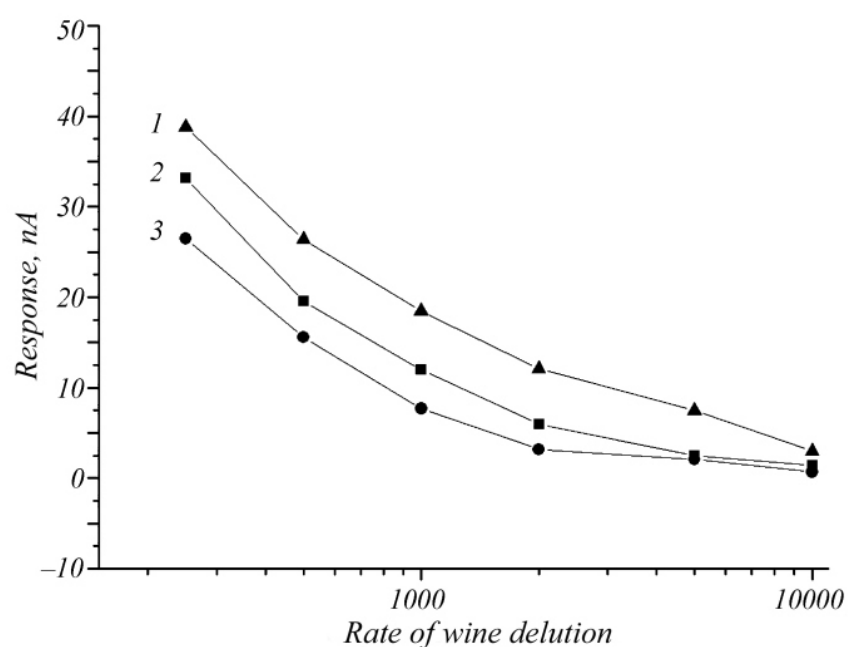

Fig. 6. Responses of amperometric biosensors based on AO, immobilized in GA vapour, to insertion of different wine aliquots into electrochemical cell: "Madeira" (19\% ethanol, curve 1), "Kara-Dag" (16\% ethanol, curve 2), "Mont Blanc" (10.5\% ethanol, curve 3). Measurement in $20 \mathrm{mM}$ phosphate buffer, $\mathrm{pH} 7.2$, potential of $+200 \mathrm{mV}$ vs inner reference electrode.

taken the maximal from obtained optimal range, i.e. by 2,000 times.

The maximum concentrations of main interfering substances in 2,000-fold diluted samples of must and wine are as follows [1]: glycerol - to $0.1 \mathrm{mM}$, glucose to $0.5 \mathrm{mM}$, lactate - to $0.03 \mathrm{mM}$, ascorbic acid - to $0.002 \mathrm{mM}$. Thus, considering the results presented in
Fig. 2, the biosensor with AO immobilized in GA is insensitive to these substances in mentioned concentrations.

To elucidate an effect of other wine components (methanol, acetate, phenol compounds, etc.) on operation of the developed transducer with AO immobilized in GA, an experiment was carried out as follows. To the "Madeira" sample (according to the distillate densitometry data, ethanol content - 19 vol. \%) AO $(2.5 \mathrm{mg})$ was added and incubated for ethanol disintegration. The $10 \mu \mathrm{l}$ samples of the mixture taken every certain interim after mixing were inserted into the electrochemical cell, and the biosensor responses were measured. It was shown that no longer than in one hour after mixture incubation the biosensor response dropped by $33 \%$, in 7 hour - by $50 \%$, and in a day when ethanol was completely disintegrated by the enzyme, the biosensor response was no more than $0.5 \mathrm{nA}$. This experiment proves high specificity and selectivity of the developed biosensor for ethanol analysis in wine.

At the next stage, the ethanol content was measured by the developed biosensor in accordance with the optimized procedure. 23 samples of different wines (dry, semi sect, dessert and strong; white, rose, red) and 2 samples of red and white must were analyzed. The results were compared with the data of traditional analysis - distillate densitometry (Table 1). Noteworthy, a high level of correlation between the results of measurements was obtained by two methods. 
Концентрація етанолу у зразках вина та виноградного сусла, визначена за допомогою біосенсора та методу денситометрії дистиляту

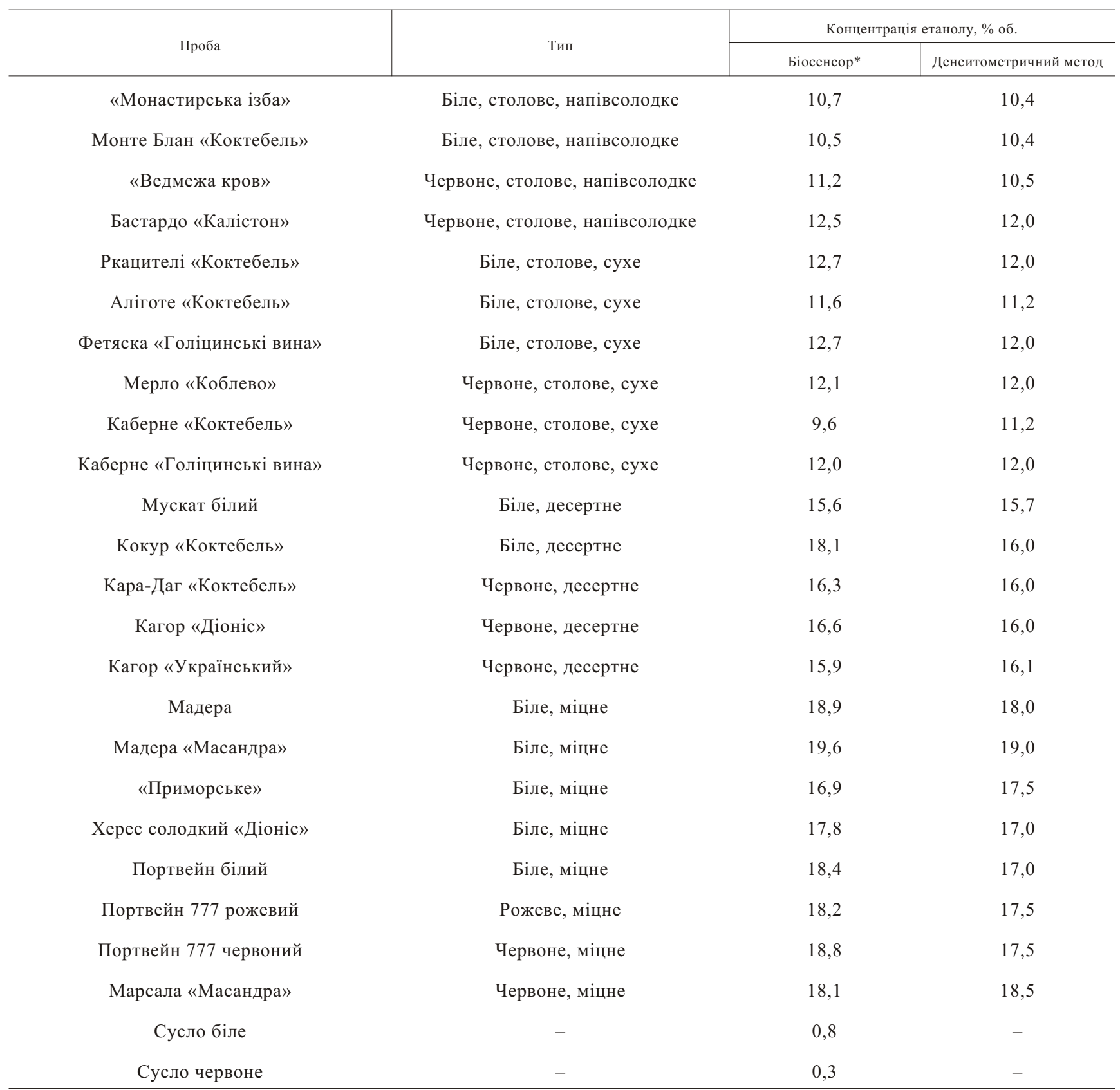

*Відносне стандартне відхилення $6,2 \%$

Thus, the procedure of ethanol determination in wine by the amperometric biosensor, based on screen-printed platinum electrode SensLab and alcohol oxidase, has been elaborated. The working characteristics of amprometric biosensors created using two methods of AO immobilization were investigated. The trans- ducer with $\mathrm{AO}$ immobilized in glutaraldehyde vapour was shown to demonstrate lower measurable limit of substrate concentration and higher stability as compared with immobilization in PEDT. That is why the first method was accepted for the development of the biosensor for ethanol analysis in wine. The $\mathrm{pH}$ opti- 
mum for this biosensor was determined, an independence of its response on buffer capacity and ion strength of working solution was proved. The level of sample dilution for analysis was optimized to eliminate the effect of wine interfering substances on biosensor operation. The ethanol concentration in various wines and must has been measured by the developed biosensor. Good correlation between the results obtained by ethanol amperometric biosensor and the data of traditional method of ethanol analysis, distillate densitometry, was stated.

\section{Т. Б. Горюшкіна, А. П. Орлова, Г. М. Верик, О. П. Солдаткін, С. В. Дзядевич}

Методика визначення етанолу у вині ферментним амперометричним біосенсором

Резюме

Мета. Розробка методики визначення етанолу у вині ферментним амперометричним біосенсором. Методи. Використано ферментний амперометричний біосенсорний метод аналізу етанолу. Результати. Проведено порівняльний аналіз ефективності застосування двох методів іммобілізаиії алкогольоксидази (АО) при розробиі амперометричного біосенсора для аналізу етанолу у вині. Обрано метод іммобілізації ферменту у nарах глутарового альдегіду, за використання якого іммобілізована АО демонструє кращі робочі характеристики. Досліджено селективність, операційну стабільність та стабільність при зберіганні створеного біосенсора, встановлено рН-оптимум його роботи. Відпрацьовано методику визначення етанолу у вині за допомогою амперометричного біосенсора на основі платинового електрода SensLab ma AO. Iз застосуванням розробленого високостабільного біосенсора проаналізовано концентрацію етанолу у зразках вина. Показано високу кореляцію отриманих результатів із даними методу денситометрії дистиляту. Висновки. Запропоновану методику аналізу етанолу можна в подальшому використовувати у виноробстві.

Ключові слова: амперометричний біосенсор, алкогольоксидаза, етанол, вино, сусло.

\section{Т. Б. Горюшкина, А. П. Орлова, Г. Н. Верик, А. П. Солдаткин,} С. В. Дзядевич

Методика определения этанола в вине ферментным амперометрическим биосенсором

\section{Резюме}

Цель. Разработка методики определения этанола в вине ферментным амперометрическим биосенсором. Методы. Использован ферментный амперометрический биосенсорный метод анализа этанола. Результаты. Проведен сравнительный анализ эффективности применения двух методов иммобилизации алкогольоксидазы (АО) при разработке амперо-метрического биосенсора для анализа этанола в вине. Выбран метод иммобилизачии фермента в парах глутарового альдегида, при исполь- зовании которого иммобилизрованная АО демон- стрирует лучшие рабочие характеристики. Исследованы селективность, операционная стабильность и стабильность при хранении созданного биосенсора, определен рН-оптимум его работы. Отработана методика определения этанола в вине с помощью амперометрического биосенсора на основе платинового электрода SensLab и AO. С применением разработанного высокостабильного биосенсора проанализирована концентрация этанола в образцах вина и сусла. Показана высокая корреляция полученных результатов $c$ данными метода денситометрии дистиллята. Выводы. Предложенную методику анализа этанола можно в дальнейшем использовать в виноделии.

Ключевые слова: амперометрический биосенсор, алкогольоксидаза, этанол, вино, сусло.

\section{REFERENCES}

1. Goriushkina T. B., Dzyadevych S. V. Grape wines. Chemical composition and methods determination // Biotechnology.2008.-1, N 2.-P. 24-38.

2. Gonchar M. V. Traditional and enzymatic methods of ethanol determination in biological solutions // Laboratornaya diagnostika.-1999.-N 1.-P. 45-49.

3. Niculescu M., Erichsen T., Sukharev V., Kerenyi Z., Csoregi E., Schuhmann $W$. Quinohemoprotein alcohol dehydrogenase-based reagentless amperometric biosensor for ethanol monitoring during wine fermentation // Anal. Chim. Acta.2002.-463, N 1.-P. 39-51.

4. Goriushkina T. B., Dzyadevych S. V. Enzyme biosensors for quantitative analysis of wine components // SEMST.-2008.N 1.-P. 49-67.

5. Lapa R., Lima J., Pinto I. Development of a sequential injection analysis system for the simultaneous biosensing of glucose and ethanol in bioreactor fermentation // Food Chem.2003.-81.-P. 141-146.

6. Segundo M., Lima J., Rangel A. Automatic flow systems based on sequential injection analysis for routine determinations in wines // Anal. Chim. Acta.-2004.-513.-P. 3-9.

7. Bucur B., Mallat E., Gurban A.-M., Gocheva Y., Velasco C., Marty J.-L., Noguer T. Strategies to develop malic acid biosensors based on malate quinone oxidoreductase (MQO) // Biosensors and Bioelectronics.-2006.-21.-P. 2290-2297.

8. Legin A., Rudnitskaya A., Lvova L., Vlasov Y., Di Natale C., $D$ 'Amico $A$. Evaluation of Italian wine by the electronic tongue: recognition, quantitative analysis and correlation with human sensory perception // Anal. Chim. Acta.-2003.484.-P. 33-44.

9. Mazzei F., Botre F., Favero G. Peroxidase based biosensors for the selective determination of $\mathrm{D}$, L-lactic acid and Lmalic acid in wines // Microchem. J.-2007.-87.-P. 81-86.

10. Azevedo A. M., Prazeres M. F., Cabral J. M. S., Fonseca L. P. Ethanol biosensors based on alcohol oxidase // Biosensors and Bioelectronics.-2005.-21.-P. 235-247.

11. Castillo J., Gaspar S., Leth S., Niculescu M., Mortari A., Bontidean I., Soukharev V., Dorneanu S. A., Ryabov A. D., Csoregi $E$. Biosensors for life quality. Design, development and applications // Sensors and Actuators B.-2004.-102.P. 179-194.

12. Patel N. G., Meier S., Cammann K., Chemnitius G. C. Screenprinted biosensors using different alcohol oxidases // Sensors and Actuators B.-2001.-75, N 1-2.-P. 101-110. 
13. Smutok O., Ngounou B., Pavlishko H., Gayda G., Gonchar $M$., Schuhmann $W$. A reagentless bienzyme amperometric biosensor based on alcohol oxidase/peroxidase and an Oscomplex modified electrodeposition paint // Sensors and Actuators B.-2006.-113, N 2.-P. 590-598.

14. Shkotova L. V., Slast'ya E. A., Zhylyakova T. A., Soldatkin A. $P$., Schuhmann W., Dzyadevych $S$. V. Amperometric biosensor for ethanol analysis in wines and must during wine fermentation // Ukr. Biochem. J.-2005.-77, N 1.-P. 96-103.

15. De Luca S., Florescu M., Ghica M. E., Lupu A., Palleschi G., Brett C. M. A., Compagnone D. Carbon film electrodes for oxidase-based enzyme sensors in food analysis // Talanta.2005.-68, N 2.-P. 171-178.

16. Gouveia-Caridade C., Pauliukaite R., Brett C. M. A. Development of electrochemical oxidase biosensors based on carbon nanotube-modified carbon film electrodes for glucose and ethanol // Electrochim. Acta.-2008.-53.-P. 6732-6739.

17. Carelli D., Centonze D., De Giglio A., Quinto M., Zambonin $P$. G. An interference-free first generation alcohol biosensor based on a gold electrode modified by an overoxidised non-conducting polypyrrole film // Anal. Chim. Acta.2006.-565.-P. 27-35.

18. De Prada A. G.-V., Pena N., Mena M. L., Reviejo A. J., Pingarron J. M. Graphite-Teflon composite bienzyme amperometric biosensors for monitoring of alcohols // Biosensors and Bioelectronics.-2003.-18,-P. 1279-1288.
19. Boujtita M., Chapleau M., Murr N. Biosensors for analysis of ethanol in food: effect of the pasting liquid // Anal. Chim. Acta.-1996.-319, N 1-2.-P. 91-96.

20. Goriushkina T. B., Shkotova L. V., Slast'ya E. A., Soldatkin A. $P$., Dzyadevych $S$. $V$. Optimization of methods of lactate determination in wine by amperometric enzyme biosensor // SEMST.-2008.-N 2.-P. 39-47.

21. Zhang S., Wright G., Yang Y. Materials and techniques for electrochemical biosensor design and construction // Biosensors and Bioelectronics.-2000.-15.-P. 273-282.

22. Sanz V., Mena M. L., Gonzelez-Cortes A., Yanez-Sedeno P., Pingarron J. M. Development of a tyrosinase biosensor based on gold nanoparticles-modified glassy carbon electrodes. Application to the measurement of a bioelectrochemical polyphenols index in wines // Anal. Chim. Acta.-2005.-528.P. 1-8.

23. Boujtita M., Hart J. P., Pittson R. Development of a disposable ethanol biosensor based on a chemically modified screen-printed electrode coated with alcohol oxidase for the analysis of beer // Biosensors and Bioelectronics.-2000.-15, N 5-6.-P. 257-263.

24. Wen G., Zhang Y., Shuang S., Dong C., Choi M. M. F. Application of a biosensor for monitoring of ethanol // Biosensors and Bioelectronics.-2007.-23, N 1.-P. 121-129.

UDC $577.15+573.6$

Received 26.03.09 